\title{
IMPLEMENTASI UNDANG-UNDANG NOMOR 6 TAHUN 2014 KEPALA DESA DALAM MENJALANKAN TUGAS DI DESA AUR KUNING KECAMATAN KAMPAR KIRI HULU KABUPATEN KAMPAR
}

\author{
Eka \\ Universitas Lancang Kuning \\ e-mail: eka@unilak.ac.id
}

\begin{abstract}
This study examines the task of village heads in carrying out their duties in Aur Kuning Village, Kampar Kiri Hulu Subdistrict, as agreed in the Regulation of the Minister of State for Administrative Reform Number: 13 of 2009 concerning Guidelines for Improving the Quality of Public Services, Rights, Duties and Obligations of Village Heads in accordance with the provisions of Law Number 6 of 2014 concerning Villages. Article 26 The Village Head who organizes the Village Government, implements Village Development, Village community development, and empoweres the Village community. The design of this study uses a qualitative descriptive method that will discuss and review secondary data related to documents relating to the Village Head in the Task Process in Aur Kuning Village, Kampar Kiri Hulu Subdistrict. In addition, so that the research objectives can involve researchers also using primary data as a result of interviews with research informants, namely: Village Chief Aur Kuning, Secretary of Desa Aur Kuning, Village Staff of Aur Kuning and Community of Desa Aur Kuning. The Village Head in Aur Kuning Village, Kampar Kiri District has been effective in the context of development. His job was as the head of Aur Kuning Village, Kampar Kiri District
\end{abstract}

Keywords: Implementation, village head, and carrying out duties

Abstrak

Penelitian ini bertujuan melihat implemtasi tugas kepala Desa dalam menjalankan tugas di Desa Aur Kuning Kecamatan Kampar Kiri Hulu, sebagaimana yang telah diamatkan dalam Peraturan Menteri Negara Pendayagunaan Aparatur Negara Nomor: 13 Tahun 2009 Tentang Pedoman Peningkatan Kualitas Pelayanan Publik wewenang, Hak, Tugas, dan Kewajiban Kepala Desa sesuai ketentuan Undang Undang Nomor 6 Tahun 2014 tentang Desa. Pasal 26 Kepala Desa bertugas menyelenggarakan Pemerintahan Desa, melaksanakan Pembangunan Desa, pembinaan kemasyarakatan Desa, dan pemberdayaan masyarakat Desa. Desain penelitian ini menggunakan metode kualitatif deskriptif yang akan memahami dan mengkaji data-data sekunder secara mendalam berupa dokumen-dokumen yang berkaitan dengan pelaksanaan Kepala Desa Dalam Menjalankan Tugas Di Desa Aur Kuning Kecamatan Kampar Kiri Hulu. Selain itu, agar tujuan penelitian dapat tercapai peneliti juga menggunakan data primer berupa hasil wawancara dengan informan penelitian yaitu: Kepala Desa Aur Kuning, Sekretaris Desa Aur Kuning, Pegawai Desa Aur Kuning dan Masyarakat desa Aur Kuning.Kesimpulan dari hasil penelitian ini menunjukkan bahwa Implementasi tugas kepala Desa di Desa Aur Kuning Kecamatan Kampar Kiri sudah efektif dalam rangka melaksanakan Pembangunan tugasnya sebagai pimpinan kepala Desa Aur Kuning Kecamatan Kampar Kiri..

Kata Kunci : Implementasi, kepala desa, dan menjalankan tugas 


\section{PENDAHULUAN}

Pemerintah sebagai penyelenggara negara mempunyai tanggung jawab kepada rakyatnya. Fungsi pemerintah adalah menyelenggarakan negara berdasarkan kewenanganya. Kewenangan yang diberikan kepada pemerintah merupakan dasar bagi pembuatan sampai penetapan kebijakan. Peran pemerintah sangat menentukan dalam menyelsaikan permasalahan yang ada dalam masyarakat. Permasalahan yang terjadi dimasyarakat akan terselsaikan dengan baik melalui kebijakan yang ditetapkan oleh pemerintah.

Di Indonesia, Implemetasi, Hak, Tugas, dan Kewajiban Kepala Desa sesuai ketentuan Undang Undang Nomor 6 Tahun 2014 tentang Desa. Pasal 26 : Kepala Desa bertugas menyelenggarakan Pemerintahan Desa, melaksanakan Pembangunan Desa, pembinaan kemasyarakatan Desa, dan pemberdayaan masyarakat Desa. Berdasarkan Undang-Undang Nomor 6 Tahun 2014 maka tugas pemerintahan desa antara lain :

a. Menyelenggarakan tugas pemerintahan desa

b. Melaksanakan pembangunan desa

c. Melakukan pembinaan ke masyarakat desa

d. Pemberdayaan masyarakat desa

Didalam Peraturan Daerah Kabupaten Kampar Nomor 12 Tahun 2017 tentang Pengangkatan dan Pemberhentian perangkat desa menyebutkan bahwa: a. Kepala desa berkedudukan sebagai kepala pemerintah desa yang memimpin penyelenggaraan pemerintahan desa. b.Kepala desa bertugas menyelenggarakan pemerintahan desa, melaksanakan pembangunan, pembinaan kemasyarakatan dan pemberdayaan masyarakat.

Tabel I.1.:Nama Desa di Kecamatan Kampar Kiri Hulu.

\begin{tabular}{|l|l|r|}
\hline No & Nama Desa & Jumlah Penduduk \\
\hline 1 & Gema & 1.032 \\
\hline 2 & Tanjung Belit & 725 \\
\hline 3 & Tj. Belit Selatan & 495 \\
\hline 4 & Muara Bio & 191 \\
\hline 5 & Batu Sanggan & 453 \\
\hline 6 & Gajah Bertalut & 465 \\
\hline 7 & Tanjung Beringin & 634 \\
\hline $\mathbf{8}$ & Aur Kuning & $\mathbf{5 8 2}$ \\
\hline 9 & Terusan & 457 \\
\hline 10 & Sebayang Jaya & 354 \\
\hline 11 & Pkln Serai & 715 \\
\hline 12 & Kota Lama & 890 \\
\hline 13 & Sungai Sonti & 304 \\
\hline 14 & Dua Sepakat & 300 \\
\hline 15 & Ludai & 457 \\
\hline 16 & Bukit Betung & 300 \\
\hline 17 & Danau Sontul & 260 \\
\hline 18 & Deras Tajak & 207 \\
\hline 19 & Batu Sasak & 937 \\
\hline 20 & Tj,. Karang & 573 \\
\hline 21 & Kebun Tinggi & 405 \\
\hline 22 & Pln Kupas & 412 \\
\hline 23 & Lubuk Bigau & 178 \\
\hline 24 & Tj. Permai & 340 \\
\hline & Jumlah & 11,666 \\
\hline
\end{tabular}

Sumber : Kantor Camat Kampar Kiri Hulu, 2018 
Kecamatan Kampar Kiri yang merupakan Kabupaten Kampar Provinsi Riau memiliki 24 desa. tabel diatas terlihat dari 24 desa, 4 desa dikategorikan desa biasa, 9 desa sulit dan 11 desa dikategorikan sangat sulit dan dari 24 desa 10 desa dengan transportasi air dan 14 desa yang sudah dilalui roda 4, namun kondisi jalan sangat memprihatinkan apalagi musim hujan tiba. Dari 24 desa hanya 4 desa yang memiliki jaringan telekomunikasi dan desa Aur Kuning termasuk kategori desa sangat sulit.

Dalam penelitian ini peneliti memilih lokasi penelitian di desa Aur Kuning yang merupakan salah satu desa yang tertinggal dari di segi tranfortasi Kecamatan Kampar Kiri.Dalam penyelenggaraan pemerintahan desa Aur Kuning Kecamatan kampar Kiri Hulu, pihak Kepala Desa melakukan beberapa upaya pemberdayaan agar dapat meningkatkan kesejahteraan masyarakat di wilayahnya hal ini tentunya menjadi tugas pokok pemerintah desa, tentu saja tidak dapat berjalan dengan baik sebagaimana yang di inginkan tanpa adanya kerjasama dan dukungan dari masyarakat, yang mana masyarakat itu sendiri subjek dari pembangunan yang artinya pembangunan itu tidak akan dapat terlaksana dengan baik tanpa adanya pertisipasi dan dukungan dari masyarakat atau seluruh masyarakat atau seluruh anggota masyarakat yang ada di daerah itu. Berdasarkan fenomena-fenomena tersebut maka peneliti tertarik untuk melakukan penelitian dengan judul "Implementasi Undang-Undang Nomor 6 tahun 2014 Kepala Desa dalam Menjalankan Tugas Di Desa Aur Kuning Kecamatan Kampar Kiri Hulu Kabupaten Kampar".

\section{METODE}

\section{Lokasi Penelitian}

Dalam Penelitian ini dilaksanakan di Desa Aur Kuning Kecamatan Kampar Kiri Hulu.

\section{Teknik Pengumpulan Data}

Pengumpulan data pada penelitian ini menggunakan beberapa teknik supaya memperoleh data yang lengkap. Adapun teknik-teknik yang digunakan dalam pengumpulan data adalah sebagai berikut:

1. Teknik Wawancara

Teknik wawancara digunakan untuk memperoleh data/informasi tentang wewenang kepala desa dalam menjalankan tugas di desa Aur Kuning Kecamatan Kampar Kiri Hulu dengan menjadikan desa Aur Kuning, Sekretaris desa Aur Kuning, pegaiwai desa Aur Kuning dan masyarakat setempat.

2. Observasi

Pada metode ini penelitian dilakukan dengan pengamatan atau melihat langsung terhadap tugas kepala Desa dalam menjalankan tugas serta untuk mendukung atau membandingkan dengan data yang diperoleh dari wawancara.

3. Teknik Dokumentasi

Teknik dokumentasi dalam penelitian ini digunakan untuk memperoleh data penunjang penelitian berupa struktur organisasi, profil lembaga dan dokumen-dokumen terkait wewenang kepala desa serta partisipasi masyarakat di desa Aur Kuning Kecamatan Kampar Kiri Hulu.

\section{Teknik Penentuan Informan dan Informan penelitian}

Penelitian ini menggunakan teknik purposive sampling untuk menentukan Informan penelitian. Hal ini dilakukan dengan berbagai pertimbangan agar tujuan dari penelitian dapat tercapai. Dalam peneliti ini berusaha secara cermat menentukan informan yang tepat. Peneliti berusaha mengetahui informan secara mendalam sehingga informan yang terpilih dapat menjawab pertanyaan-pertanyaan yang diajukan dengan tepat sehingga diharapkan tujuan penelitian dapat tercapai. 


\section{Teknik Validasi Data}

Dalam menguji validitas data penelitian ini menggunakan teknik triangulasi, karena sumber data serta teknik pengumpulan data banyak dan beragam maka dapat diuji validitas sebagaimana data dikatan valid apabila terdapat informasi yang sama dari sumber yang berbeda atau dengan menggunakan teknik pengumpulan yang berbeda. Hal ini dilakukan untuk menghindari terjadinya bias yang terjadi pada informan kunci (key informant bias). Untuk melakukan triangulasi peneliti memeriksa validitas data dengan membandingkan hasil dari teknik pengumpulan yang berbeda (teknik triangulasi) atau membandingkan hasil dari sumber yang berbeda (triangulasi sumber).

\section{Analisis Data}

Dalam melaksanakan Teknik analisis data yang digunakana dalam penelitian ini adalah analisis interaktif. Data yang diperoleh berupa kata-kata atau kalimat yang dipisah menurut kategorinya kemudian dianalisis untuk mendapatkan gambaran mengenai fakta yang ada atau untuk memperoleh kesimpulan.

Langkah-langkah teknik analisis data yang digunakan adalah:

1. Reduksi Data

Reduksi data adalah memilah-milah data, difokuskan pada hal-hal yang penting.Laporan lapangan sebagai bahan mentah disederhanakan, direduksi, disusun lebih sistematis, ditonjolkan pokok-pokok yang penting sehingga lebih mudah dikendalikan.Reduksi ini dapat pula membantu memberikan kode pada aspek-aspek tertentu. Reduksi data sebagai proses pemulihan pemusatan perhatian atau penyederhanaan, pengabstrakan dan transformasi data kasar yang muncul dari catatan lapangan. Reduksi data berlangsung terus menerus selama proses penelitian berlangsung dan berlanjut terus sesudah penelitian lapangan sampai laporan akhir lengkap.

2. Penyajian Data

Penyajian data merupakan upaya penyususnan sekumpulan informasi ke dalam suatu matriks/konfigurasi yang mudah dipahami. Penyajian data yang mudah dipahami adalah cara utama menganalisis data kualitatif yang valid.

3. Menarik Kesimpulan

Data-data yang diperoleh pada waktu observasi dan penelitian dikumpulkan. Kemudian data tersebut dihubungkan dan dibandingkan antara satu dengan yang lain sehingga mudah ditarik kesimpulan sebagai jawaban atas setiap permasalahan yang ada. Setelah kesimpulan diambil maka dapat diperoleh gambaran yang jelas mengenai efektivitas partisipasi masyarakat dalam peningkatan pelayanan publik di Kelurahan Tobekgodang Kecamatan Tampan

\section{HASIL DAN PEMBAHASAN}

Menyelenggarakan tugas pemerintahan desa Dalam melaksanakan tugasnya Kepala Desa mempunyai wewenang memimpin penyelenggaraan pemerintahan desa berdasarkan kebijakan yang ditetapkan bersama BPD dan mengajukan rancangan peraturan desa menetapkan peraturan desa yang telah mendapat persetujuan bersama BPD menyusun dan mengajukan rancangan peraturan desa mengenai APBDesa untuk dibahas dan ditetapkan bersama BPD.

Berikut wawancara dengan informan penelitian:

“ Dalam menyelenggarakan tugas pemerintahan desa, kepala Desa mengikuti pertauran yang telah ditetapkan oleh pemerintah terhadap desa sesuai dengan perturan yang berlaku dan menggadakan musyawarah bersama BPD. Penerapan tugas sebagai kepala Desa sebagai pemerintahan dalam segala hal yang menyangkut pembangunan, penggunaan uang ADD desa yg sesuai peraturan desa.kemudian dibahas bersama BPD. Kemudian di sahkan maka program penyelenggaraan pembangun untuk 
kepentingan masyarakat desa ( hasil wawancara dengan Bapak kapala Desa Aur Kuning, pada tanggal 24 juli 2018)

Kemudian dilanjutkan wawancara wawancara dengan BPD desa Aur Kuning mengenai pelaksanaan pembangunan Desa.

“ Dalam pembangunan Desa peran penting BPD sangat membantu Kepala Desa menyelesaikan pembangun untuk kepentingan masyarakat untuk perekonomian akses jalan yag sudah dibangun di Desa.Insfrastruktur desa sangat memberikan dampak baik terhadap masyarakat baik itu berupa jalan aspal dan kemudahan akses terhadap masyarakat Desa. (hasil wawancara dengan Bapak BPD Desa Aur Kuning, pada tanggal 24 juli 2018)

a. Melaksanakan pembangunan desa

Pembangunan Desa dilaksanakan sesuai dengan Rencana Kerja Pemerintah Desa dan dilaksanakan oleh Pemerintah Desa dengan melibatkan seluruh masyarakat Desa dengan semangat gotong royong serta memanfaatkan kearifan lokal dan sumber daya alam Desa.

Wawancara dengan Kepala Desa Aur Kuning.

"Pembangunan Desa dilaksanakan sesuai dengan Rencana Kerja Pemerintah Desa. Pembangunan Desa sebagaimana dimaksud disini tugas yang dilaksanakan oleh Pemerintah Desa dengan melibatkan seluruh masyarakat Desa dengan semangat gotong royong. Pelaksanaan Pembangunan Desa dilakukan dengan memanfaatkan kearifan lokal dan sumber daya alam Desa. Pembangunan lokal berskala Desa dilaksanakan sendiri oleh Desa. Pelaksanaan program sektoral yang masuk ke Desa diinformasikan kepada Pemerintah Desa untuk diintegrasikan dengan Pembangunan Desa. ( hasil wawancara dengan Bapak kapala Desa Aur Kuning, pada tanggal 24 juli 2018)

b. Melakukan Pembinaan ke Masyarkat Desa.

Pembinaan kemasyarakatan merupakan salah satu program pemerintah dalam meningkatkan serta mengelola lembaga dan sumber daya manusia agar lebih baik dan bekerja sesuai dengan harapan. Pembinaan kemasyarakat dapat dilakukan dengan berbagai cara baik melalui pelatihan, rapat, lomba, peringatan hari besar dan lain-lain.

Berikut wawancara dengan informan penelitian:

“ dalam pelaksanaan pembangunan Desa, perlu di perhatikan masyarakat lokal setempat untuk mengetahui hal-hal yang berkaitan dengan lingkungan. Seperti dalam hal pembinaan kepada masyarakat program-programpelatihan, rapat, lomba, kerajinan dan kegiatan yang besar lainnya. Kegiatan yang menyangkut ekonomi masyarakat dan memberikan dampak kepada nmasyarkat setempat, supaya masyarakat khususnya Ibu-ibu rumahtangga. (hasil wawancara dengan Bapak BPD Desa Aur Kuning, pada tanggal 24 juli 2018)

c. Pemberdayaan Masyarakat Desa

Pemberdayaan masyarakat desa adalah upaya untuk mengembangkan kemandirian dan kesejahteraan masyarakat engan meningkatkan pengetahuan, sikap, keterampilan, perilaku, kemampuan, kesadaran, serta memanfaatkan sumber daya melalui penetapan kebijakan, program, kegiatan, dan pendampingan yang sesuai dengan esensi masalah dan prioritas kebutuhan masyarakat desa. Dalam buku Tanya Jawab Seputar Undang-Undang Desa Kementerian Desa menjawab beberapa pertanyaan yang banyak dipertanyakan tentang konsep pemberdayaan masyarakat desa.

Wawancara dengan Kepala Desa Aur Kuning.

"Pemberdayaan masyarakat desa bertujuan untuk memampukan desa dalam melakukan tindakan bersama sebagai suatu kesatuan yang melibatkan berbagai pemangku kepentingan ditingkat pemerintah desa, masyarakat desa, maupun pihak lain untuk mendorong partisipasi dan mendayagunakan kemampuan masyarakat desa dalam proses pembangunan desa, menyusun perencanaan pembangunan yang berpihak pada kelompok miskin, serta meningkatkan kapasitas dan kualitas sumberdaya manusia di desa. ( hasil wawancara dengan Bapak kapala Desa Aur Kuning, pada tanggal 24 juli 2018) 
Wawancara dengan Kepala Desa Aur Kuning tentang Peraturan Desa.

"Sesuai PP no 43 tahun 2014, pemberdayaan masyarakat desa bisa melibatkan pihak ketiga yang diberi mandat secara jelas untuk melakanakan pemberdayaan. Pemberdayaan masyarakat desa dilaksanakan oleh pemerintah desa,_BPD, forum musyawarah desa, BUM Desa, BKAD, forum kerja sama desa dan kelompok kegiatan masyarakat lain yang dibentuk untuk mendukung kegiatan pemerintahan dan pembangunan pada umumnya." ( hasil wawancara dengan Bapak kapala Desa Aur Kuning, pada tanggal 24 juli 2018).

\section{KESIMPULAN}

Berdasarkan hasil dan pembahasan yang telah diuraikan oleh peneliti pada bab sebelumnya, maka peneliti menyimpulkan bahwa kesimpulan dari hasil penelitian ini menunjukkan bahwa emplementasi kebijakan di Desa Aur Kuning Kecamatan Kampar Kiri Hulu sudah efektif dalam rangka peningkatan Pembangunan Masyarakat Desa dengan adanya terkendala akses infrastruktur yang belum siap di Desa Aur Kuning Kecamatan Kampar Kiri Hulu. Namun masih perlu adanya pembenahan sarana dan prasarana, serta ketersediaan sumber daya manusia.

\section{SARAN}

Setelah peneliti melakukan penelitian, kemudian membahas dan menarik kesimpulan tentang Implementasi Undang-Undang Nomor 6 tahun 2014 Kepala Desa dalam Menjalankan Tugas Di Desa Aur Kuning Kecamatan Kampar Kiri Hulu Kabupaten Kampar, maka peneliti mengemukakan saran perlu adanya perhatian khusus dari pemerintahan Kota Kabuapten Kampar untuk Pembangunan Desa yang tertinggal dan pembenahan pembenahan sarana dan prasarana bagi kebutuhan masyarakat, serta ketersediaan sumber daya manusia yang tersedia yang lebih baik ke depannya

\section{DAFTAR PUSTAKA}

[1]. A., Djumino, Wahyudin, M, 2002, Pengaruh Kepemimpinan dan Motivasi Terhadap Kinerja Karyawan, Tesis, Tidak dipublikasikan

[2]. Abdul Wahab, Solichin. 2008. Pengantar Analisis Kebijakan Publik. Malang: Universitas Muhammadiyah Malang Press.

[3]. A.W. Widjaja, 1996, Pemerintahan Desa dan Administrasi Desa Menurut Undang-Undang Nomor 5 Tahun 1979 (sebuah Tinjauan), Jakarta, PT Raja Grafindo Persada

[4]. Dwidjowijoto, Riant Nugroho. (2004) Kebijakan Publik: Formulasi, Implementasi, dan Evaluasi, Jakarta : PT. Elex Media Komputindo.

[5]. Purwanto, Erwan A. dan Dyah Ratih Sulistyastuti. Implementasi Kebijakan Publik :Konsep dan Aplikasinya di Indonesia. Yogyakarta: Gava Media.2012. 
[6]. Arikunto. S. 2006. Prosedur penelitian suatu pendekatan praktek. Jakarta: PT Rhineka Cipta

[7]. Dwiyanto, agus, dkk. 2012. Reformasi birokrasi publik di Indonesia. Yogyakarta: Gadjah mada university press

[8]. Dwiyanto, agus. 2012. Manejemen pelayanan publik: peduli, inklusif, dan kalaboratif. Yokyakarata: Gadjah mada university press

[9]. Dwiyanto, Agus. 2014. Mewujudkan Good Governance Melalui Pelayanan Publik. Yogyakarta : Gadjah Mada University Press.

[10]. Fathoni, abdurrahmat. 2011. Metologi penelitian dan teknik penyusunan skripsi. Jakarta: Rineka cipta.

[11]. Herdiansyah, Haris. 2010. Metodologi Penelitian kualitatif untuk Ilmu-ilmu Sosial. Jakarta: Salemba Empat.

[12]. Keputusan BPD Desa Salakan Kecamatan Teras, Kabupaten Boyolali Nomor. 1 Tahun 2013 Tentang Tata Tertib BPD.

[13]. Nurcholis, Hanif. 2005. Teori dan Praktik Pemerintahan dan Otonomi Daerah. Jakarta: PT Gramedia Widiasarana Indonesia.

[14]. Nurdin, Syafruddin dan Usman, Basyiruddin. 2003. Guru Profesional dan Implementasi Kurikulum. Jakarta: Ciputat Press.

[15]. Phinanditia. 2010. "Fungsi dan Wewenang Badan Permusyawaratan Desa dalam Penyelenggaraan pemerintah Desa” (Skripsi S-1). Serang: Universitas Sultan Agung Tirtayasa.

[16]. Rani Ika Ramayanti. 2008. "Kinerja Badan Permusyawaratan Desa (BPD) Pulungdowo Kecamatan Tumpang Kabupaten Malang” (Skripsi S-1). Malang: UM.

[17]. Sugiyono. 2010. Metode Penelitian Pendidikan Pendekatan Kuantitatif, Kualitatif, dan R\&D. Bandung: Alfabeta.

[19]. Viky Zulkarnain. 2013. "Efektivitas Fungsi Badan Permusyawaratan Desa (BPD) dalam Penyelenggaraan Pemerintahan Desa di Kabupaten Tulungagung”(Skripsi S-1). Malang: UM.

[20]. Widjaja. 2003. Otonomi Desa Merupakan Otonomi yang Bulat dan Utuh. Jakarta: PT. Raja grafindo Persada 